\title{
A new dataset and empirical relationships between magnitude/intensity and epicentral distance for liquefaction in central-eastern Sicily
}

\author{
Claudia Pirrotta, Maria Serafina Barbano, Pierpaolo Guarnieri and Flavia Gerardi \\ Dipartimento di Scienze Geologiche, Università degli Studi di Catania, Italy
}

\begin{abstract}
Strong earthquakes can trigger several phenomena inducing soil deformation, such as liquefaction, ground fracturing and landslides, which can often cause more damage than the seismic shaking itself. A research performed on numerous historical accounts reporting descriptions of seismogeological effects in central-eastern Sicily, allowed the authors to update the previous liquefaction datasets. 75 liquefaction-induced phenomena observed in 26 sites, triggered by 14 earthquakes, have been used to define relationships between intensity/magnitude values and epicentral distance from the liquefied sites. The proposed upper bound-curves, at regional scale for central-eastern Sicily, are realized by using the updating liquefaction dataset and also the new CPTI04 Italian earthquake parametric catalogue. These relationships can be useful in hazard assessment to evaluate the minimum energy of an earthquake inducing liquefactions.
\end{abstract}

Key words seismo-induced effects - liquefaction dataset-magnitude-distance relationships - geologic hazard - Sicily

\section{Introduction}

Liquefaction is one of the most common ground deformation effects of earthquakes and often a major cause of damage and destruction to buildings and infrastructures. Liquefaction evidence is considered geological marker of paleoseismicity (seismites), because sites affected by past liquefaction have the potential to liquefy again.

Mailing address: Dr. Claudia Pirrotta, Dipartimento di Scienze Geologiche, Università di Catania, Corso Italia 55, 95129 Catania, Italy; e-mail: c.pirrotta@unict.it
Numerous and widespread liquefaction phenomena have been triggered by earthquakes in several places of the world and many studies have revealed a strong relationship between earthquake parameters and maximum epicentral or fault distance from the sites in which liquefaction develops. These studies are useful to engineers and urban planners for seismic hazard assessment and the mitigation of seismic risk (Russ, 1982; Talwani and Cox, 1985; Saucier, 1989; Amick et al., 1990).

Italian historical records offer several descriptions of seismogeological effects which occurred during the last millennium, such as landslides, liquefaction and ground fracturing. These records were used to compile several catalogues and liquefaction prone area maps.

Eastern Sicily is a seismically active area in which some of the most disastrous Italian events, with $M_{a w}$ up to 7.4 ( $M_{a w}$ equivalent moment magnitude according to Working Group CPTI04, 2004), have occurred (e.g., the 1169, 


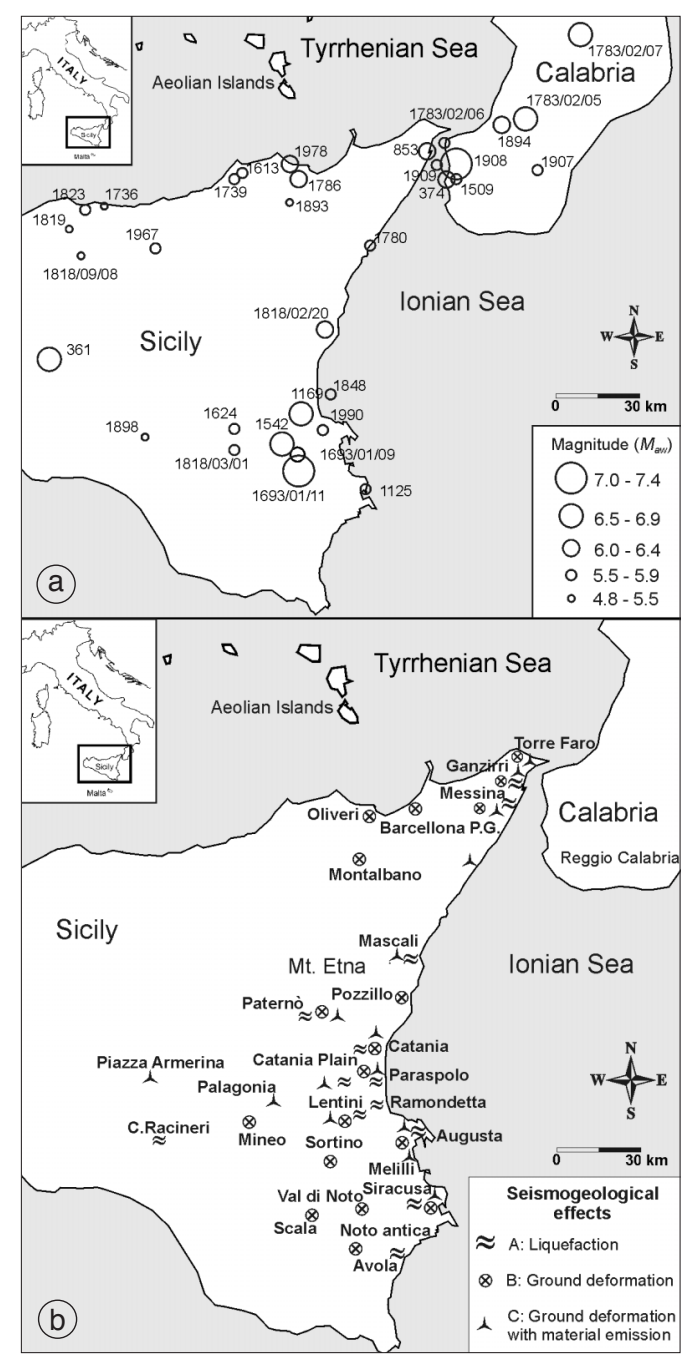

Fig. 1a,b. a) Epicentral map of the earthquakes of central-eastern Sicily and Southern Calabria, data from the Italian Earthquake Parametric Catalogue (Working Group CPTI04, 2004); the circles are earthquake epicentres with magnitudes higher than 4.8. b) Distribution map of the seismogeological effects, classified in table I, retrieved from historical sources (table II).

1693 and 1908 earthquakes) (fig. 1a,b) causing damage, numerous fatalities and triggering several ground failures, as reported by historical sources. This region was also affected by some strong earthquakes occurred in Southern Calabria, such as the 1783 seismic sequences.

Geological evidence of liquefactions (fig. $2 a)$, correlated to some of the strongest earthquakes of Eastern Sicily, were found in the Holocene deposits in the Mascali area, which extends in the eastern flank of Mount Etna, and in the Catania Plain (fig. 1b), both characterized by a continental fluviatile sedimentation environment (Guarnieri et al., 2008).

The aim of this paper is to revise and update the previous liquefaction dataset, and to define empirical relationships, for central-eastern Sicily, between earthquake magnitude/intensity and maximum epicentral distance of liquefied sites, using the earthquake source parameters retrieved from the recent Italian Earthquake Parametric Catalogue (Working Group CPTI04, 2004).

\section{Earthquake-induced liquefaction}

Earthquake-induced liquefaction is a process by which saturated granular sediment loses its strength, due to ground shaking. Seismic shear waves generated by strong-motion earthquakes produce inter-particle shear stresses which, in saturated soil, can induce significant increasing of pore-water pressures. The increase induces loss of shear resistance of the sediment and the soil can undergo large viscous deformations. This mechanism typically triggers in sandy deposits, even though cases of liquefaction in gravel-rich deposits are documented (Wong et al., 1975; Bezerra et al., 2005).

The liquefaction occurrence depends on the local site conditions (soil composition, local stratigraphic and topographic amplification) and on earthquake characteristics, such as magnitude and distance, which control shaking duration (i.e. number of cycles and amplitude of imposed shear stress). Usually, the minimum earthquake magnitude value for liquefying sand is estimated to be about 5.5-6 (Ambraseys, 1991; Valera et al., 1994), while for gravel-rich deposits about 7 (Valera et al., 1994).

Earthquake-induced liquefactions commonly produce sedimentary structures such as dikes, sand boils and lateral spreading (Obermeier, 
Table I. Classification of the ground features, associated to liquefaction phenomenon. A class embraces the liquefaction features s.s., B class the ground deformation and $\mathrm{C}$ class also includes water, gas and bituminous material emission.

\section{A}

sand boils, sand hills and sand/mud volcano
B

Ground deformation

B1

Ground fracturing

B2

Ground settlement

B3

Ground fracturing

and settlement
$\mathrm{C}$

Ground deformation

with material emission
$\mathrm{C} 1$

Ground fracturing with gases exhalation

C2

Ground fracturing

with hot water, bituminous material and/or fluids emission and/or gases exhalation

C3

Ground fracturing and settlement with water and/or gases exhalation

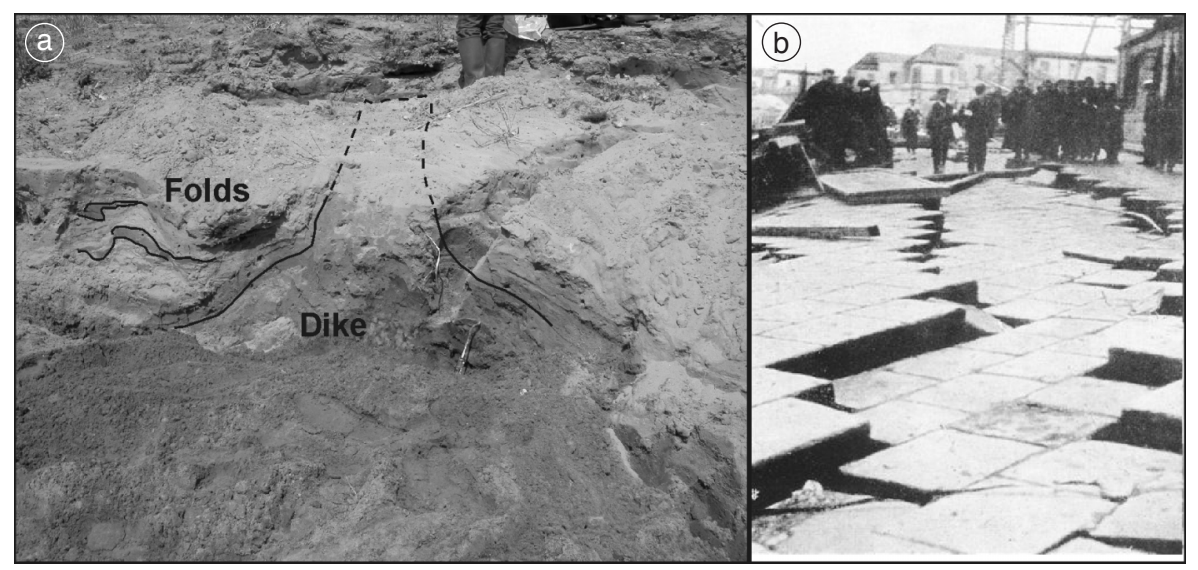

Fig. 2a,b. Examples of liquefaction features in Eastern Sicily: a) surveyed by means of paleo-seismological analysis in the Catania plain (after Guarnieri et al., 2008); b) from historical reports, liquefaction in the Messina harbour after the 1908 earthquakes (after Baratta, 1910).

1996) (fig. 2a). These features generally develop near the epicentral area, more numerous and consistent in the mesoseismic area, decreasing systematically with the distance from the epicentre (Obermeier, 1998).

The liquefaction occurs underground and the developed structures not always reach the ground surface. In these cases the seismo-induced liquefaction can be revealed by others associated phenomena such as surface deformation, differential compaction, local swelling or collapse (fig. 2b), differential settlement of building (e.g., Kuribayashi and Tatsuoka, 1975; Galli, 2000); moreover, ground fissures with water or fluids emission, can be superficial evidence of liquefaction.

\section{The new dataset of historical liquefaction phenomena in central-eastern Sicily}

Italian historical bibliography offers numerous accounts describing seismo-induced effects 


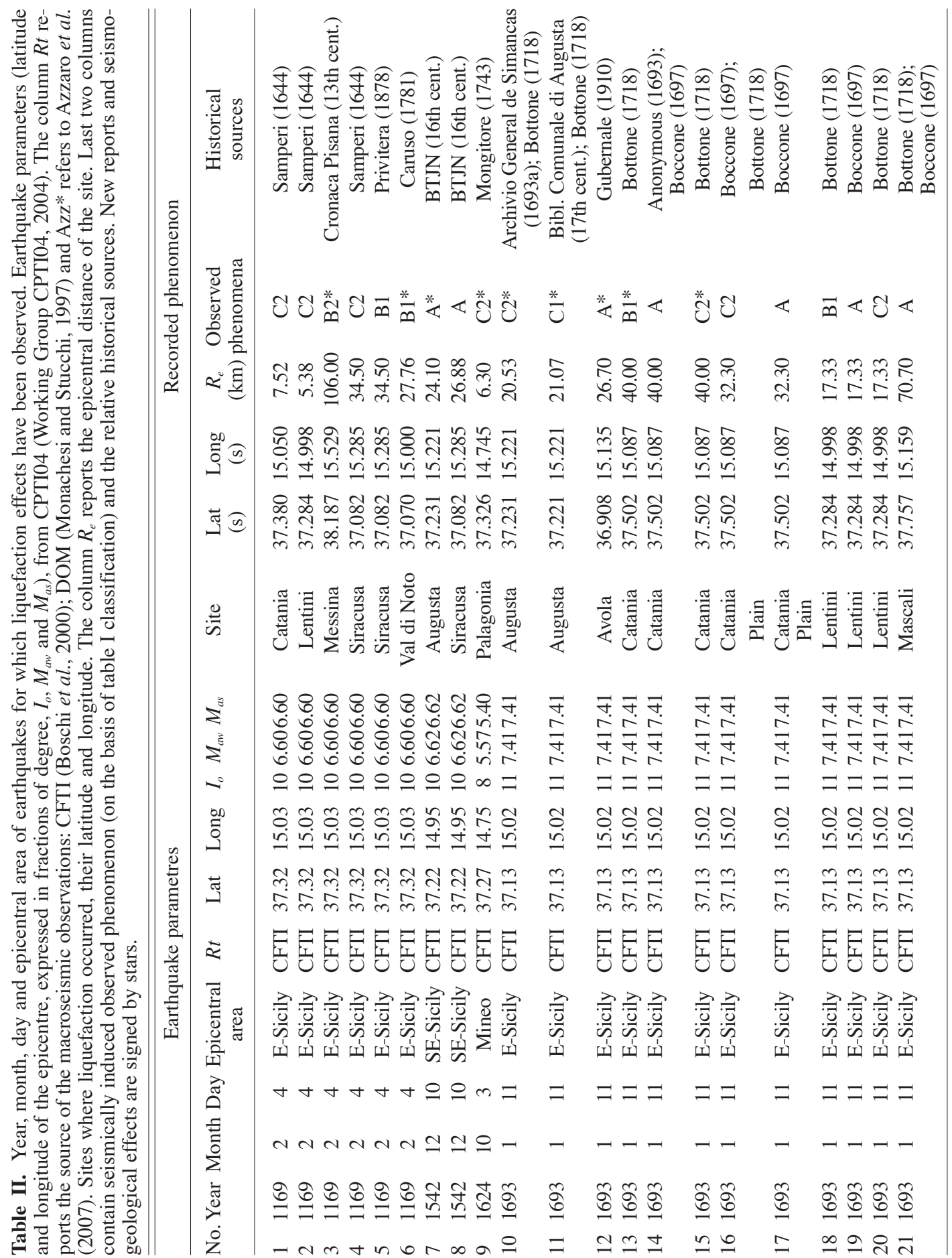




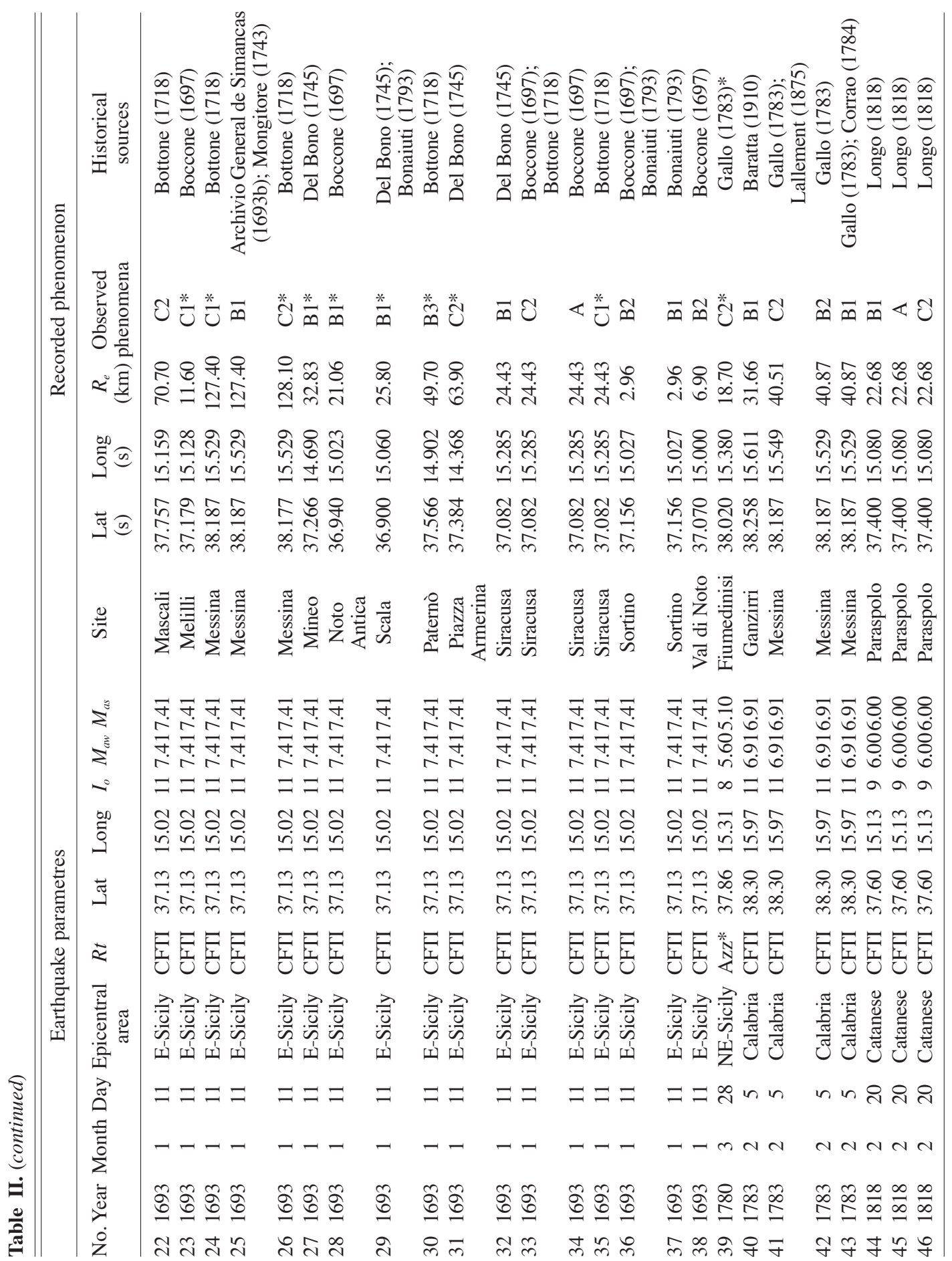




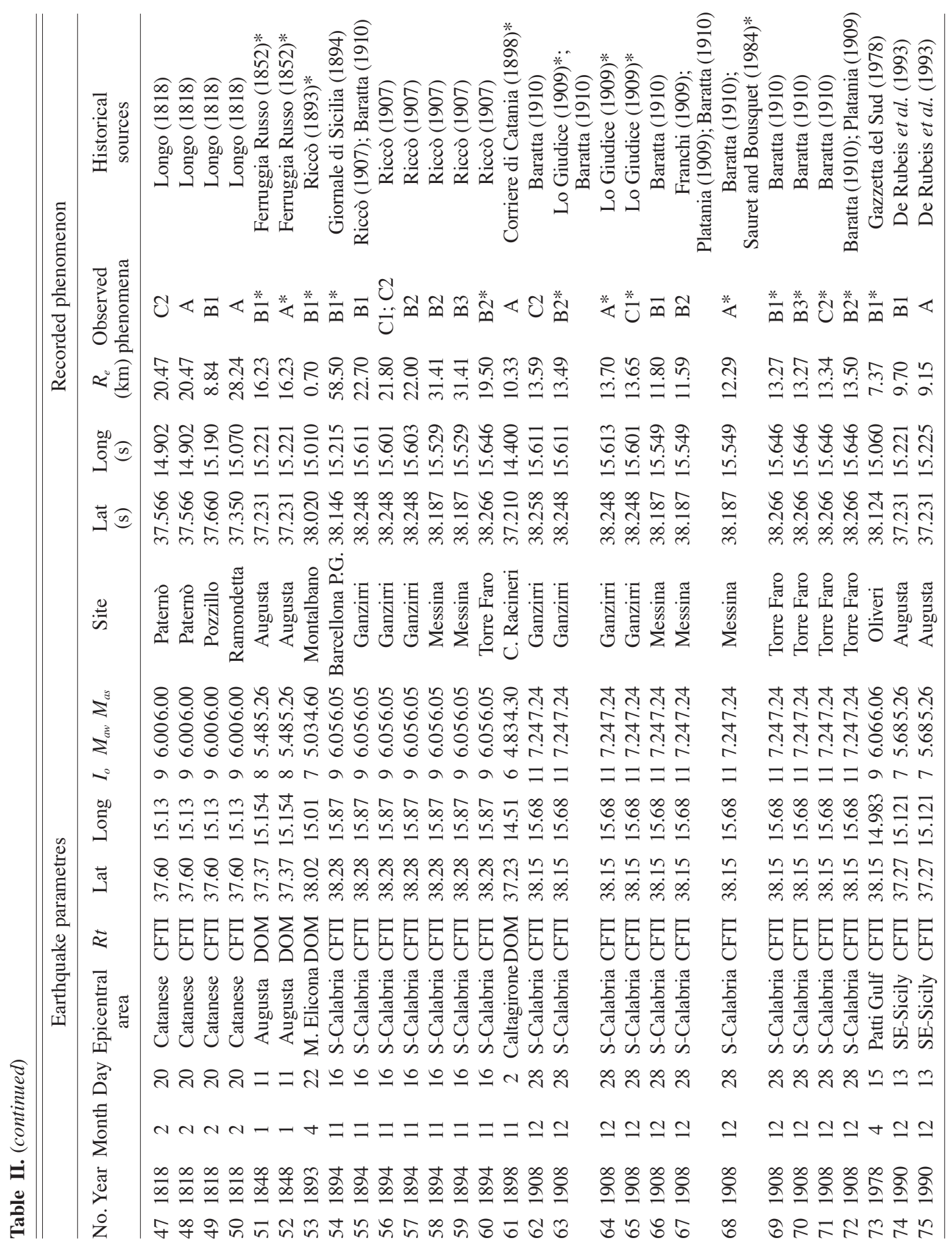


which are reported in catalogues (Berardi et al., 1991; Galli and Ferreli, 1995; Romeo and Delfino, 1997; Boschi et al., 2000; Galli, 2000; Prestininzi and Romeo, 2000); these have also been used to draw maps of liquefaction-prone areas of Italy (Galli and Meloni, 1993) and, at local scale, of historical liquefaction-induced phenomena in the Catania area (Azzaro, 1999).

This paper presents an updated dataset of liquefaction phenomena in central-eastern Sicily, realized through the revision of historical accounts, retrieved from the aforementioned catalogues and through an original research of historical primary sources. Besides liquefaction structures developing at the surface (i.e. sand boils, dikes and mud volcanoes), effects directly connected to the liquefaction mechanism at depth (fig. 2b) have also been reported. Soil deformation phenomena related to liquefaction, according to the classification of Galli (2000) and to geological and geomorphologic criteria, have been chosen, i.e. ground fissuring, collapse and surface settlements occurred in recent alluvial depositional areas, flat enough to suggest a their deep liquefaction-induced origin. For example Bottone (1718) describes the effects observed during the 1693 earthquake in the Catania plain as follows: «la terra si aprì in modo spropositato... Da questa fenditura fuoriuscì una polla di acqua calda: si osservò che ciò era avvenuto in molti luoghi della pianura» (The ground surface excessively opened... The crack ejected hot water: this phenomenon was observed in several places of the plain). Using the same criteria, exhalation of gases and fluids occurred together with sediment liquefaction, as described for 1908, 1894 and 1783 earthquakes by Lo Giudice (1909) and Baratta (1910), have been included.

The ground features, associated to liquefaction phenomenon, have been classified into three groups: A class, liquefaction features s.s.; B class, ground deformation; C class, ground deformation with emission of material (table I).

The new dataset (table II) collects 75 liquefaction effects observed in 26 sites triggered by 14 earthquakes occurred in central-eastern Sicily and Southern Calabria, from 1169 A.D. to 1990 A.D., and also contains the new earthquake parameters, location, epicentral intensity $I_{o}$ (MCS), magnitude, $M_{a w}$ (equivalent moment magnitude)
Table III. Number of liquefaction cases for $M_{a w}$ interval. Column 3 is the number of events that induced liquefaction, to be compared with the total number of events existing in the CPTI04 earthquake catalogue (Working Group CPTI04, 2004) for magnitude interval classes at the same epicentral distance.

\begin{tabular}{cccc}
\hline \hline$M_{a w}$ interval No. liquefactions & No. events & $\begin{array}{c}\text { Events } \\
\text { in CPTI04 }\end{array}$ \\
\hline $7.0-7.5$ & 40 & 2 & 2 \\
$6.6-6.9$ & 11 & 3 & 4 \\
$6.0-6.5$ & 15 & 3 & 6 \\
$5.6-5.9$ & 3 & 2 & 6 \\
$5.0-5.5$ & 4 & 3 & 75 \\
$4.6-4.9$ & 1 & 1 & 62 \\
\hline
\end{tabular}

and $M_{a s}$ (surface wave magnitude), reported by the CPTI04 Catalogue (Working Group CPTI04, 2004) and the epicentral distance $R_{e}$, for each liquefied site. The epicentral intensity $\left(I_{o}\right)$ varies from 6 to 11 MCS (table II); the magnitude $M_{a w}$ from 4.83 to 7.41 ; and the $M_{a s}$ from 4.3 to 7.41 .

Table III summarises the frequency of occurrence of liquefaction phenomena for magnitude classes. $69 \%$ of observed liquefaction features are induced by earthquakes with $M_{a w} \geq 6.6$; while $24 \%$ are related to $M_{a w}$ ranging from 5.6 to 6.5 and only $7 \%$ for $M_{a w}<5.5$.

\section{Relationships between magnitude/ intensity versus epicentral distance $\left(\boldsymbol{R}_{e}\right)$}

Several studies have been carried out to acquire empirical relationships between earthquake source parameters (magnitude, intensity, etc.) and maximum epicentral or fault distance of liquefied sites at regional scale and worldwide. These relationships are useful tools both in geotechnical applications, such as microzonation studies and hazard assessment at the regional scale, and in seismic application, i.e. for the evaluation of the minimum energy of an earthquake capable to induce liquefaction and of the minimum magnitude of paleo-earthquakes which have caused liquefaction in a given site, finally for the recognition of the probable mesoseismic zone.

Kuribayashi and Tatsuoka (1975) obtained the correlation between maximum epicentral dis- 

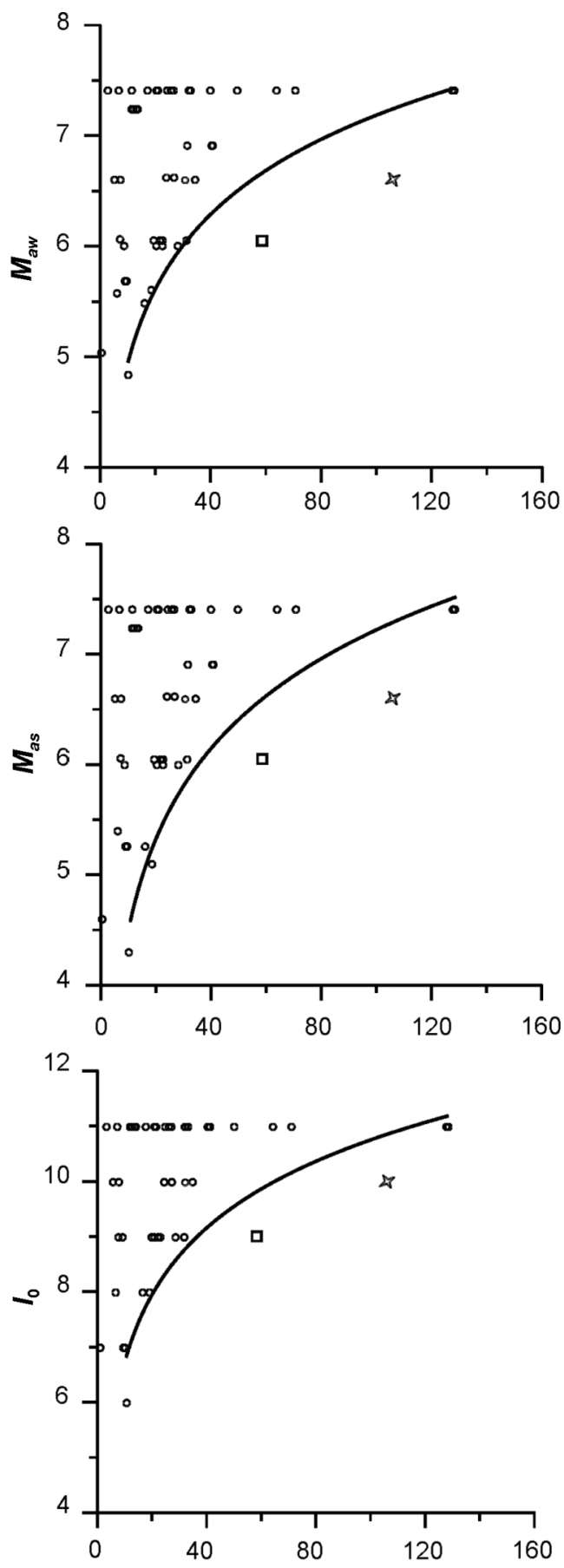

Epicentral distance (km) tance of liquefied sites and associated magnitude for strong earthquakes of Japan. Ambraseys (1991) considered both epicentral and fault distance to compute the relationships between moment-magnitude and distance for 137 liquefaction events scattered around the world. Papadopoulos and Lefkopoulos (1993) obtained a bounding equation revisiting the worldwide curves proposed by Ambraseys (1991), adding their Greek data and other liquefaction observations in several places of the world. Recently, the magnitude upper bound method was applied by Galli (2000) to historical liquefactions induced by 61 earthquakes occurred in Italy from 1117 A.D. to 1990 A.D. The author related epicentral intensity $I_{o}(\mathrm{MCS})$, magnitude $M_{s}$ and equivalent moment magnitude $M_{e}$, reported in the previous version of the Italian parametric catalogue (Working Group CPTI99, 1999), to the epicentral distance $R_{e}$; finally, magnitude $M_{s}$ to the epicentral distance $R_{e}$ considering only the instrumentally observed values for the period 1900 A.D.-1990 A.D. Prestininzi and Romeo (2000) found for the whole Italian territory maximum epicentral distances at which ground failures occur as a function of epicentral intensity, distinguishing induced ground effects in topographic changes, liquefaction, landslides and fractures.

The regional dataset realized in this work has been used to find local relationships between earthquake source parameters, $M_{a w}, M_{s}$ and $I_{o}$ from CPTI04 (Working Group CPTI04, 2004) and the epicentral distance of the liquefied sites $\left(R_{e}\right)$. We selected these parameters because most of the historical earthquakes have not instrumental data; $M_{a w}$ is the parameter that could be linked to the earthquake energy being computed from $I_{o}$ and the extension of the felt area (Gasperini et al., 1999).

Fig. 3. Distribution of earthquakes that induced liquefaction effects for the period 1169-1990 in terms of epicentral distances and $M_{a w}$ values, $M_{a s}$ values and $I_{o}$ values. $M_{a w}, M_{a s}$ and $I_{o}$ are from CPTI04 (Working Group CPTI04, 2004). The upper bound equations are reported in the text as eq. (4.1), eq. (4.2) and eq. (4.3), respectively. The polygons correspond to the anomalous points: star to the Messina site for the 1169 earthquake; square refers to Barcellona site for the 1894 earthquake. 
In the magnitude/intensity-epicentral distance graphs, the point distribution shows the area of occurrence of liquefaction effects (fig. 3 ), the best-fit of the farthest points gives the upper bound-curves, delimiting liquefactionprone areas, whose equations (1,2 and 3$)$ are reported below

$$
\begin{gathered}
M_{a w}=(2.67 \pm 0.04)+(0.98 \pm 0.01) \ln \left(R_{e}\right) \\
M_{a s}=(1.85 \pm 0.28)+(1.16 \pm 0.06) \ln \left(R_{e}\right) \\
I_{o}=(2.77 \pm 0.32)+(1.73 \pm 0.06) \ln \left(R_{e}\right)
\end{gathered}
$$

\section{Discussion}

The upper bound curves $\left(M_{a w}, M_{s}\right.$ and $I_{o}$ versus $R_{e}$ ) obtained for central-eastern Sicily show a similar trend and highlight that lower intensity earthquakes have caused liquefaction at very close distance from the epicentre $(<10 \mathrm{~km})$; $43 \%$ of the observations occurred with lowmedium magnitude (intensity VIII-IX MCS) within $50 \mathrm{~km}$ from the epicentre. Finally the events with $M_{a w}>6.6$ (intensity X-XI) induced liquefaction at great distances, particularly earthquakes with $M_{a w}>7.0$ and intensity XI (MCS) can trigger liquefaction as far as $\sim 130$ $\mathrm{km}$ from the epicentre (fig. 3).

Only two points fall out of the upper bound curve, in the area where no liquefaction is predicted. One of these points refers to ground fracturing observed in the Messina seaport during the 1169 earthquake and another point refers to a ground fracture observed near the Barcellona P.G. village after the 1894 earthquake (fig. 3). These sites are both located in north-eastern Sicily. Liquefaction at such exceptionally great distance from the epicentres, as observed for the previous two sites (table II and fig. 3), may be due to local geological characters, but may also be explained with both mislocation and a magnitude/intensity wrong estimate of the 1169 and 1894 earthquakes.
Moreover, the liquefaction prone areas show a lack of data for $6 \leq M \leq 7.4$ and $9 \leq I_{o} \leq 11$ and epicentral distance between 40 and $120 \mathrm{~km}$ (fig. 3), indicating that the earthquakes with these magnitude intervals $(1169,1542,1783$, 1894, 1908 and 1978 events) could have triggered liquefaction outer from the study area. This lack of data could be due to the inevitable incompleteness of the dataset, assembled from historical accounts, and to the fact that the study region not always embraces the entire mesoseismic area of the analyzed earthquakes. In fact the epicentres of the 1783 and 1894 earthquakes are localized in Southern Calabria; the 1908 event is located in the Messina Strait; the 1169 and 1542 sources are close to the southeastern coast of Sicily, finally the 1978 epicentre is located in the Tyrrhenian Sea (fig. 1).

Comparing ours upper bound curves to previous ones of several regions of the world

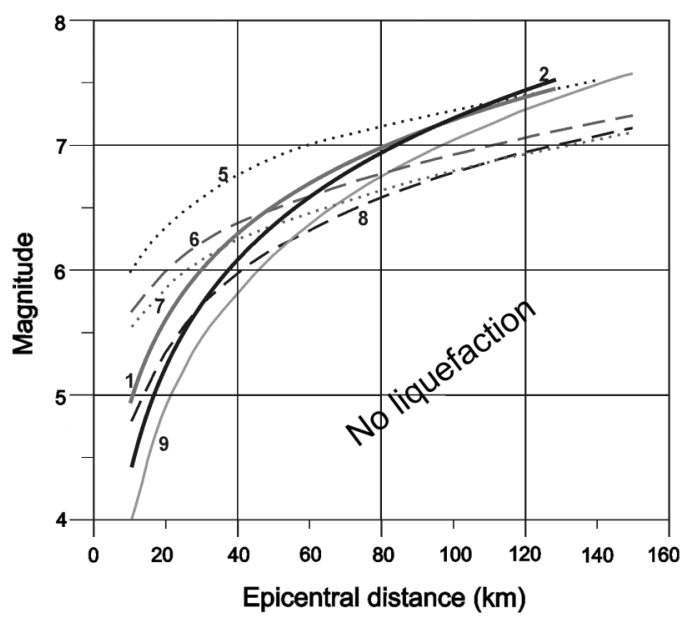

Fig. 4. Comparison between different upper bound curves from literature and those proposed in this paper: continuous dark grey line (1) and continuous black line (2) are related to ours $M_{a w}$ and $M_{a s}$ relationships, respectively; dot black line (5) is related to $M$ values from Kuribayashi and Tatsuoka (1975); dashed grey line (6) to $M_{w}$ from Ambraseys (1991); dot light grey line (7) to $M_{s}$ from Papadopulos and Lefkopulos (1993); dashed black line (8) to $M_{e}$ (equivalent magnitude) values and continuous light grey line (9) to $M_{s}$ ones from Galli (2000). 


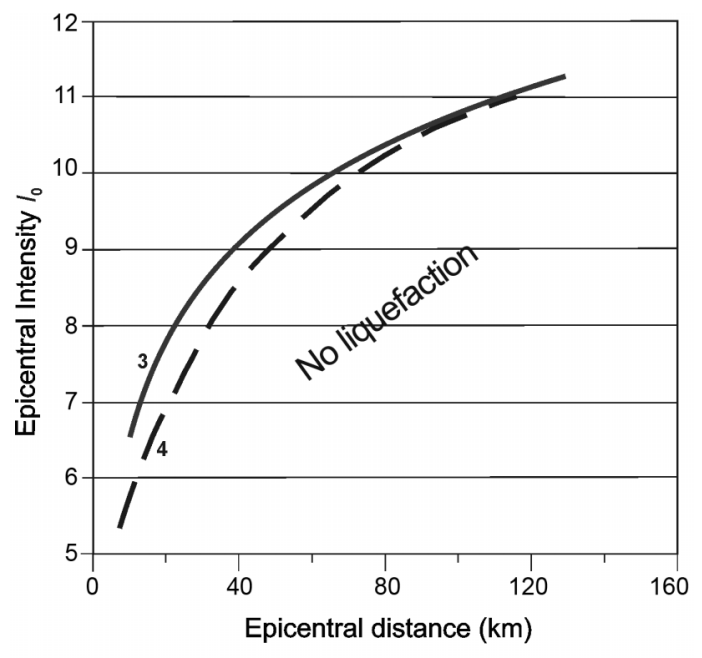

Fig. 5. Comparison between the upper bound curves concerning epicentral intensity $I_{o}$ provided by Galli (2000), dashed line (4), and that proposed in this paper, continuous line (3).

(Kuribayashi and Tatsuoka, 1975; Ambraseys, 1991; Papadopoulos and Lefkopoulos, 1993) and of the Italian country (Galli, 2000), it is possible to observe a good correspondence of the curve trends as it regards the surface wave magnitude $M_{s}$ versus $R_{e}$ curve (9) from Galli (2000) (fig. 4) and between our $I_{o}$ versus $R_{e}$ curve and Galli's one (fig. 5). Mismatch found with the $M_{e}$ (equivalent magnitude) versus $R_{e}$ curve (8) (fig. 4) can be explained with the different source parameters used by the authors.

\section{Conclusions}

The analysis performed on historical sources has enriched previous compilations of liquefaction-induced phenomena that occurred during the last millennium in central-eastern Sicily. New data have been introduced and some of the known historical accounts have been reconsidered also including environmental effects directly connected to the liquefaction mechanism, chosen on the basis of geological and geomorphologic criteria.

The new dataset contains 75 liquefaction phenomena triggered by 14 earthquakes, with $I_{o}>6$
(MCS) and $M_{a w}>4.6$, in 26 sites of central-eastern Sicily, and source parameters retrieved from the new Italian earthquake catalogue (Working Group CPTI04, 2004).

Most of the liquefactions are connected to earthquakes with magnitude more than 5.4; only under peculiar site condition, can liquefactions be triggered by earthquakes with $M_{a w}$ value less than 5.4, as observed for the 1893 Montalbano Elicona earthquake $\left(M_{a w}=5.03\right)$ and the 1898 Caltagirone earthquake $\left(M_{a w}=4.83\right)$.

The updating of the previous catalogues of liquefaction effects and the use of the data retrieved from the Parametric Catalogue (CPTI04), allowed us to obtain a version, at regional scale, of the upper bound curves, $M_{a w}, M_{a s}$ and $I_{o}$ versus $R_{e}$, for central-eastern Sicily.

Liquefaction effects described at great distance suggest that the studied area is particularly sensitive to these kinds of phenomena, probably due to the seismological characters of the region and to the distribution of Holocene deposits. Moreover, liquefaction effects that fall out of the bound-curve could reveal mislocation and/or wrong magnitude estimate of historical seismic events such as for the 1169 and 1894 earthquakes.

These relationships may be considered a tool for evaluating the minimum energy of an earthquake inducing liquefaction effects, useful in paleoseismic analyses and hazard evaluation, i.e. for engineering applications and for the Civil Protection Department, especially in areas subject to industrial and urban growth.

\section{Acknowledgements}

This work was funded by the Italian Civil Defence through INGV-DPC Project S2, grants to MSB. We are indebted with P.M. De Martini and D. Pantosti for the helpful discussion. We also thank the anonymous reviewers that with their criticism and suggestion contributed to substantially improve the original manuscript.

\section{REFERENCES}

Ambraseys, N.N. (1991): Engineering seismology, Int. J. Earthq. Eng. Struct. Dyn, 17, 1-105. 
Amick, D., R. Gelinas, G. Maurath, H. Cannon, D. Moor, E. BILlington and H. Kempinen (1990): Paleoliquefaction features along the Atlantic seabord, U.S.N.R.C, Washington DC 20555 NRC FIN D 1682, NUREG/CR-5613 RA.

ANONYMUOS (1693): Vera relazione di quello che è successo nell'ultimo terremoto in Sicilia (veritable ralation de ce qui s'est passé dans le dernier tremblement de terre en Sicile), Toulon.

Archivio General de Simancas (1693a): Relazione del governatore del Porto di Messina B. Bazan al Vicerè di Napoli sui danni causati in Sicilia dai terremoti del $9 e$ 11 gennaio, 1693, Secretarìa de Estado, Negociòn de Sicilia, legajo 3507 (1693-94), Consultas decretos y notas, no. 4.

Archivio General de Simancas (1693b): Relazione dei luoghi che hanno sofferto in Sicilia nei Terremoti dal nove di gennaio fino al cinque di febbraio del 1693 che si sono sentite ventuno scosse, le primi tre grandi e le altre più lievi, Palermo febbraio 1693, Secretarìa de Estado, Negociòn de Sicilia, legajo 3507 (1693-94), Consultas decretos y notas, no. 11 .

AzZARO, R. (1999): Liquefaction induced features for the scenario earthquake in the Catania area, in The Catania Project: Earthquake Damage Scenarios for High Risk Area in the Mediterranean, edited by E. FAcCIOLI and V. Pessina (CNR - Gruppo Nazionale per la Difesa Terremoti, Roma), 42-45.

Azzaro, R., F. Bernardini, R. CAmassi and V. Castelli (2007): The 1780 seismic sequence in NE Sicily (Italy): shifting an underestimated and mislocated earthquake to a seismically low rate zone, Nat. Hazards, 42 (1), 149-167.

Baratta, M. (1910): La Catastrofe Sismica Calabro Messinese (28 dicembre 1908), Roma, 2, 211-426.

Berardi, R., C. Margottini, D. Molin and A. Parisi (1991): Soil liquefaction: case histories in Italy, Tectonophysics, 193, 141-164.

BeZERRA, F. H. R., V. P. DA Fonseca, C. Vita-FinZi, F.P. LiMA-FILHO and A. SAADI (2005): Liquefaction-induced structures in Quaternary alluvial gravels and gravelly sediments, NE Brazil, Eng. Geol., 76, 191-208.

Biblioteca Comunale di Augusta (17th cent.): Cronaca dei terremoti del 9 e 11 gennaio 1693 scritta da una monaca del Monastero di S. Caterina di Augusta (ms), Raccolta Blasco, vol. 638.

Boccone, P. (1697): Intorno il terremoto della Sicilia seguito l'anno 1693, Museo di Fisica, Venezia 1697, pp. 31.

Bonaiuti, V. (1793): Particolarità intorno al tremuoto che ruinò la Sicilia nel 1693, in Compendio delle Transazioni Filosofiche della Società Reale di Londra, parte 1 (Storia Naturale), tomo 1 (Vulcani e Tremuoti), 33-43, Venezia.

Boschi, E., E. Guidoboni, G. Ferrari, P. Gasperini, D. Mariotti and G. VAlensise (2000): Catalogue of strong Italian earthquakes from 461 a.C. to 1997, Ann. Geofis., 43 (4), 843-868 and CD-ROM.

BotTone, D. (1718): De immani Trinacrie terremotu. Idea historico-physica, in qua non solum telluris concussiones transacte recensetur, sed novissime anni 1717, Messina.

BTJN (16th cent.): Lettera from Yosef Ha-Kohen to Yishaq
ha-Kohen, Raccolta epistolare KM 55 (ms), The Jewish National and University Library.

Caruso, G.B. (1781): Storia di Sicilia, p. II, libro V, p. 360, Palermo.

Corrao, A. (1784): Memoria sopra i tremuoti di Messina accaduti nell'anno 1783, Messina.

Corriere di Catania (1898), Novembre, Catania.

Cronaca Pisana (13th cent.), in Italia sacra edited by F. UGHELLI, 10, Venezia 1722.

Del Bono, M. (1745): Discorso sull'origine dé tremuoti, in cui si esamina di proposito una nuova Opinione intorno alla cagione di essi, Palermo.

De Rubeis, V., C. Gasparini, A. Maramai and A. Anzidei (1993): Il terremoto siciliano del 13 Dicembre 1990, in Contributi allo studio del terremoto della Sicilia orientale del 13 Dicembre 1990, Roma, 9-44.

FerrugGia-Russo, S. (1852): Memoria sul tremuoto degli 11 gennaro 1848, Siracusa, pp. 61.

FRANCHI, S. (1909): Il terremoto del 28 dicembre 1908 a Messina, in rapporto alla natura del terreno ed alla riedificazione della città, Boll. Comit. Geol. Ital., 4th series, 10, 111-157.

Galli, P. (2000): New empirical relationships between magnitude and distance for liquefaction, Tectonophysics, 324, 169-187.

Galli, P. and L. Ferreli (1995): A methodological approach for historical liquefaction research, Paleoseismol., Assoc. Eng. Geol. Spec. Publ., 6, 36-48.

GALLi, P. and F. MELONi (1993): Nuovo catalogo nazionale dei processi di liquefazione avvenuti in occasione dei terremoti storici in Italia, Il Quaternario, 271-292.

GALLO, A. (1783): Lettera istorico-fisica dé terremoti accaduti in Messina nel mese di febbraio di quest'anno 1783, scritta dal Sig. D. Andrea Gallo, Messina 8 Marzo, in Dei terremoti di Messina e di Calabria dell'anno 1783, Memorie e riflessioni, edited by M. Augusti, Bologna, 7-18.

Gasperini, P., F. Bernardini, G. VAlensise and E. Boschi (1999): Defining seismogenic sources from historical earthquake felt report, Bull. Seismol. Soc. Am., 89, 94110.

Gazzetta del Sud (1978), Aprile 27, a. 27, n. 115, Messina.

Giornale di Sicilia (1894), Novembre 24/25, Palermo.

Guarnieri, P., C. Pirrotta, M.S. Barbano, P.M. De Martini, F. Gerardi, D. Pantosti and A. Smedile (2008): Paleoseismic investigation of historical liquefactions along the Ionian coast of Sicily, J. Earthq. Eng. (in press).

Gubernale, G. (1910): Brevi cenni sulla città di Avola, Modica.

KuRIBAyASHI, E. and F. TATSUOKA (1975): Brief reviewer of liquefaction during earthquakes in Japan, Soil Foundations, 15 (4), 81-92.

LALlement, M. (1785): Relation envoyée par M. Lallement, viceconsult de France a Messine, au ministre, in J.C.R. de Saint-Non, 'Vojage pittoresque à Naples et en Sicile', vol. 4, parte I, pp. 5-10.

Lo GiUdice, P. (1909): I laghi di Ganzirri e del Faro (Messina) dopo il terremoto del 28 Dicembre 1908, Riv. Mensile Pesca Idrobiol., Anno XI, Luglio-Agosto, 7-8.

Longo, A. (1818): Memoria storico-fisica sul tremuoto dé 20 febbraio 1818, Catania 1818.

MonACHESI, G. and M. STUCCHI (1997): DOM4.1, un data- 
base di osservazioni macrosismiche di terremoti di area italiana al di sopra della soglia del danno, GNDT, Rapporto Interno, Milano-Macerata.

Mongitore, A. (1743): Istoria cronologica de' terremoti di Sicilia, in Della Sicilia Ricercata nelle Cose più Memorabili, 2, 345-445, Palermo.

ObermeIER, S.P. (1996): Use of liquefaction-induced features for paleoseismic analysis- An overview of how seismic liquefaction features can be distinguished from other features and how their regional distribution and properties of source sediment can be used to infer the location and strength of Holocene paleo-earthquakes, Eng. Geol., 44, 1-76.

OBERMEIER, S.P. (1998): Liquefaction evidence for strong earthquakes of Holocene and latest Pleistocene ages in the states of Indiana and Illinois, U.S.A., US Geol. Surv., MS 955, 12201 Sunrise Valley Drive, Reston, VI 20192, U.S.A

Papadopoulos, G.A. and G. Lefkopulos (1993): Magnitude-distance relations for liquefaction in soil from earthquakes, Bull. Seismol. Soc. Am., 83, 925-938.

Platania, G. (1909): Il Maremoto dello Stretto di Messina del 28 dicembre 1908, Boll. Soc. Sism. It., 13, 369-458.

PrestininZI, A. and R. Romeo (2000): Earthquake-induced ground failures in Italy, Eng. Geol., 58 (3-4), 387-397.

Privitera, S. (1878): Storia di Siracusa antica e moderna (ristampa anastatica, Sala Bolognese), Napoli, 1878.

Riccò, A. (1893): Periodo di attività geodinamica dal 22 aprile alla fine di maggio1893, Boll. Acc. Gioenia Sc. Nat., n.s., 33, 16-17.

Riccò, A. (1907): Il terremoto del 16 novembre 1894 in Calabria ed in Sicilia. Parte I: Relazione sismologia, in Ann.Uff. Meteor. Geodin. Ital., s. II, 19 (1897), 7-261.

Romeo, R. and L. Delfino (1997): Catalogo Nazionale degli Effetti Deformativi del Suolo Indotti da Forti Terremoti, CEDIT, Rapporto Tecnico SSN/RT/97/04.

Russ, D.P. (1982): Style and significance of surface defor- mation in the vicinity of New Madrid, Missouri, in Investigations of the New Madrid, Missouri, earthquake region, edited by F.A. MCKEOWN and L.C. PAKISER, US Geol. Surv., Prof. Paper 1236, 95-114.

SAMPERI, P. (1644): Cronologia della gloriosa Vergine Madre di Dio Maria protettrice di Messina, Messina, 1644.

SAUCIER, R.T. (1989): Evidence for episodic sand-blow activity during the 1811-1812 New Madrid (Missouri) earthquake series, Geology, 17, 103-106.

Sauret, B. and J.C. Bousquet (1984): Manifestations d'instabilité du sol dans la zone epicentrale du seisme de Messine de 1908: le role de la liquefaction, Mouvements de Terrains, Papers of the Colloquium, 83, 5470.

Talwani, P. and J. Cox (1985): Paleoseismic Evidence for Recurrence of Earthquakes near Charleston, South Carolina, Science, 229, 379-381.

Valera, J.E., M.L. TraubeniK, J.A. Egan and J.Y. KANESHIRO (1994): A practical perspective on liquefaction of gravels, in Ground Failures Under Seismic Conditions, edited by S. Prakash and P. Dakoulas, Am. Civil. Eng. Geotech., Spec. Publ., 44, 241-257.

Wong, R.T., H.B. SEED and C.K.ChAN (1975): Cyclic loading liquefaction of gravely soils, J. Geotech, Eng. Am. Soc. Civil Eng., 277-283.

Working Group CPTI99 (1999): Catalogo Parametrico dei Terremoti Italiani (ING, GNDT, SGA, SSN, Bologna), pp. 92.

WorkING GROUP CPTI04 (2004): Catalogo Parametrico dei Terremoti Italiani, versione 2004, CPTI04 (INGV, Bologna), (available on line at http://emidius.mi.ingv.it/ CPTI/).

(received August 22, 2007;

accepted March 11, 2008) 